\title{
Journal of Apicultural Research
}

\section{The antibacterial, anti-biofilm, anti-inflammatory and virulence inhibition properties of Portuguese honeys}

\author{
Carina Isabel da Silva, Smail Aazza, Maria Leonor Faleiro, Maria da Graça \\ Miguel \& Luis Neto
}

To cite this article: Carina Isabel da Silva, Smail Aazza, Maria Leonor Faleiro, Maria da Graça Miguel \& Luis Neto (2016) The antibacterial, anti-biofilm, anti-inflammatory and virulence inhibition properties of Portuguese honeys, Journal of Apicultural Research, 55:4, 292-304, DOI: 10.1080/00218839.2016.1243294

To link to this article: https://doi.org/10.1080/00218839.2016.1243294

盟 Published online: 14 Nov 2016.

Submit your article to this journal $\sqsubset$

Џ Article views: 136

View Crossmark data ¿

Citing articles: 5 View citing articles 5 


\title{
ORIGINAL RESEARCH ARTICLE
}

\section{The antibacterial, anti-biofilm, anti-inflammatory and virulence inhibition properties of Portuguese honeys}

\author{
Carina Isabel da Silva ${ }^{a}$, Smail Aazza $^{b}$, Maria Leonor Faleiro ${ }^{a *}$ (D), Maria da Graça Miguel ${ }^{b}$ (D) and Luis Neto ${ }^{c}$ (D) \\ ${ }^{a} F C T$, Centro de Investigação em Biomedicina, Universidade do Algarve, Faro, Portugal; ${ }^{b} F C T$, MeditBio, Universidade do Algarve, Faro, Portugal; \\ 'Study Center of Agricultural Sciences and Technology, Faculdade de Ciências e Tecnologia, Universidade do Algarve, Faro, Portugal
}

(Received 6 June 2016; accepted 6 September 2016)

\begin{abstract}
In Portugal, beekeeping activity has a significant weight among livestock production. The antimicrobial activities of Portuguese honeys have been reported, but the anti-biofilm formation and anti-virulence abilities have not been investigated. The main goal of this work was to study the impact of three monofloral honeys (citrus, lavender and strawberry tree) honeys on adherence of Staphylococcus aureus, methicillin-resistant S. aureus (MRSA) and Pseudomonas aeruginosa, as well as the influence of the same honeys on virulence using Galleria mellonella as a model. In addition, the general physico-chemical characterization of these honeys and the microbial quality were also performed. The anti-inflammatory activity was also estimated by analyzing the activity of the enzymes hyaluronidase and lipoxygenase. The tested honeys complied with European legislation and no microbial contamination was observed. Of all the honeys at 12.5 and $25 \%, w / v$ the citrus honey caused the highest inhibitory activity against $P$. aeruginosa. Strawberry tree honey at $25 \% \mathrm{w} / \mathrm{v}$ was able to significantly inhibit the MRSA strains. Anti-biofilm formation and anti-inflammatory activities were observed. The different honeys impaired the virulence of S. aureus and MRSA strains. The Portuguese honeys were capable of combating the tested bacterial pathogens not only by inhibiting their growth but also by affecting important pathogenicity properties, such as adherence and virulence.
\end{abstract}

Propiedades antibacterianas, anti-biofilm, anti-inflamatorias y de inhibición de la virulencia de mieles portuguesas

\begin{abstract}
En Portugal, la actividad apícola tiene un peso significativo entre la producción ganadera. Las actividades antimicrobianas de las mieles portuguesas han sido reportadas, pero la capacidad de formación antibiofilm y la habilidad anti-virulencia no se han investigado. El objetivo principal de este trabajo fue estudiar el impacto de tres mieles monoflorales (cítricos, lavanda y madroño) en la adhesión de Staphylococcus aureus, S. aureus resistente a la meticilina (SARM) y Pseudomonas aeruginosa, así como la influencia de la mismas mieles sobre la virulencia utilizando Galleria mellonella como modelo. Además, también se llevaron a cabo la caracterización físico-química general de estas mieles y la calidad microbiana. La actividad anti-inflamatoria también se estimó mediante el análisis de la actividad de la hialuronidasa y enzimas lipoxigenasa. Se observó que las mieles analizadas cumplían con la legislación europea y que no había contaminación microbiana. De todas las mieles al 12.5 y $25 \%$, p/v, la miel de cítricos causó la mayor actividad inhibidora frente a $P$. aeruginosa. La miel de madroño al $25 \% \mathrm{p} / \mathrm{v}$ fue capaz de inhibir significativamente las cepas de SARM. Se observó actividad formación anti-biofilm y anti-inflamatoria. Los diferentes tipos de miel deterioraron la virulencia de las cepas de $S$. aureus y SARM. Las mieles portuguesas fueron capaces de combatir los patógenos bacterianos ensayados no sólo mediante la inhibición de su crecimiento, sino también al afectar propiedades importantes de patogenicidad, como la adherencia y la virulencia.
\end{abstract}

Keywords: antibacterial activity; anti-inflammatory; biofilm; virulence

\section{Introduction}

Honey production in Europe in 2010 reached almost $220,000 \mathrm{t}$ with a total number of beekeepers of 620,000 (Chauzat et al., 20I3). In Portugal the number of beekeepers is about 17,291 with a total number of colonies of 580,065 representing a $4.2 \%$ of the total having a mean of colonies per beekeeper of 33.6 (Chauzat et al., 2013). The production of honey in Portugal is in the range of 1000-10,000 t (Chauzat et al., 20I3). The edafoclimatic conditions in Portugal are particularly beneficial to the development of beekeeping and related activities, such as the production of propolis, royal jelly and beeswax.
The use of honey goes far beyond as a sweetener agent and food preservative. It is also recognized for its therapeutic role, in particular in the treatment of burns, skin ulcers, gastrointestinal disorders, cough and asthma (Biglari et al., 2012; Bukhari et al., 20Il; Cohen et al., 2012; Erguder et al., 2008; Lin, Molan, \& Cursons, 20II). In virtue of this, the honey properties, such as antioxidant, antimicrobial, anti-inflammatory activities have been reported (Abd-El, El-Hadidy, El-Mashad, \& ElSebaie, 2007; Beretta, Granata, Ferrero, Orioli, \& Facino, 2005; Bogdanov, Jurendic, Sieber, \& Gallmann, 2008; Finola, Lasagno, \& Marioli, 2007; Tan et al., 2009). 
The antibacterial activity of manuka honey against resistant Staphylococcus aureus strains (Jenkins, Burton, \& Cooper, 201I; Jenkins, Wootton, Howe, \& Cooper, 20I2) and Pseudomonas aeruginosa has been investigated (Roberts, Maddocks, \& Cooper, 2012). Vancomycin and methicillin resistant $S$. aureus exhibit a minimum inhibitory concentration (MIC) value for manuka honey of about $\leq 6 \% \mathrm{w} / \mathrm{v}$ (Jenkins et al., 20II, 20I2), however a higher concentration was required to control the growth of $P$. aeruginosa, a MIC of $12 \% \mathrm{w} / \mathrm{v}$ was found (Roberts et al., 20I2).

Many times, the impairment of healing wounds is associated to the formation of biofilm with diminished susceptibility to antibiotics and antiseptics. In addition, the raising of prevalence of antibiotic-resistant strains leads to search urgently effective antimicrobials (Cooper, Jenkins, \& Hooper, 20I4). Honey, mainly from manuka origin, has demonstrated to be effective as antibiofilm agent. In addition, such honey has also been reported as possessing a synergistic effect when associated with vancomycin against $S$. aureus biofilms, as well as an additive effect with gentamicin against $P$. aeruginosa biofilms (Campeau \& Patel, 20l4; Maddocks, Jenkins, Rowlands, Purdy, \& Cooper, 2013; Okhiria, Henriques, Burton, Peters, \& Cooper, 2009).

Virulence is the ability of a pathogen to cause disease, due to the presence of pathogen components (virulence factors), which are non-essential to in vitro growth in adequate media, nevertheless during an infection of a host, the virulence is triggered. For this reason, anti-virulence drugs may be an interesting approach of controlling pathogenic bacteria without affecting commensal microbiota. In addition, using anti-virulence drugs, less probability of development of cross-resistance with antibiotics or even new modes of resistance is expected, since these compounds did not affect directly the microorganism viability (Allen, Popat, Diggle, \& Brown, 20l4; Fernebro, 20II). Manuka honey has been reported as possessing anti-virulence ability on several pathogenic microorganisms (Jenkins, Burton, \& Cooper, 2014).

The antimicrobial activity of commercial Portuguese honeys showed a low activity against yeasts (Gomes, Dias, Moreira, Rodrigues, \& Estevinho, 2010). The characterization of organic honeys produced in the North region of Portugal evidenced several chemical characteristics as causes of variability in mesophiles and molds counts, in particular the moisture value, ash, acidity and HMF (Estevinho, Feás, Seijas, \& Vázquez-Tato, 20I2). The flavonoid content had a higher effect on either mesophiles or mold counts than the sucrose content (Estevinho et al., 20I2). Although the antimicrobial capacity of Portuguese honeys of diverse floral origin detected by these authors, very few studies have been reported considering the capacity of Portuguese honeys to prevent or disrupt biofilms, as well as their anti-virulence capacities.
Inflammation may be initiated by bacterial infection and/or chemical injury giving rise to cell injury or death. Tissue injury originates release of inflammatory mediators, such as prostaglandins, leukotrienes and related eicosanoids, through enzymatic reactions in which lipoxygenases, cyclooxygenases and phospholipase $A_{2}$ are involved (Nakamura et al., 2003; Paterson et al., 2003). Lipoxygenase catalyzes the conversion of arachidonic acid into leukotrienes. In addition, hyaluronidase is one of the enzymes responsible for the degradation of the extracellular matrix associated with inflammatory response (Granica, Czerwińska, Piwowarski, Ziaja, \& Kiss, 2013).

The aim of the present work was (a) to evaluate the antimicrobial capacity of three Portuguese monofloral honeys (citrus, lavender and strawberry tree) on S. aureus, methicillin-resistant $S$. aureus (MRSA) and $P$. aeruginosa; (b) the capacity of these honeys to prevent or disrupt biofilm formation; (c) the anti-virulence capacity of the same honeys using the Galleria mellonella model. An infection is almost always associated with inflammatory processes. For this reason, the anti-inflammatory ability of the same honeys was also evaluated using two in vitro methods.

\section{Materials and methods \\ Honey samples}

The selected honeys were monofloral and were representative of the production of the Algarve region; strawberry tree, citrus and lavender. The tested honey samples are commercial samples, which were a gift from the beekeepers Association "Associação dos Apicultores do Sudoeste Alentejano e Costa Vicentina" (AASACV). During the study the honey samples were maintained in the dark at room temperature. For each honey three flasks were provided. Three determinations were performed for each flask. The opening of the honey flasks was done under aseptic conditions, in a flow chamber (BIOHAZARD, Bio II A, Telstar; Madrid, Spain).

\section{Moisture content}

Moisture content of the honey samples was determined by measuring the refractive index (Abbe Refractometer, HANNA, HI96860I; Romania) at $20{ }^{\circ} \mathrm{C}$ according to International Honey Commission (IHC) guidelines (Bogdanov, 2002).

\section{Electrical conductivity}

Electrical conductivity was measured according to IHC guidelines (Bogdanov, 2002) using a conductivity meter (Thermo Electron Corporation, Orion 3 STAR, USA) equipped with a conductivity probe (Orion 0I3005, MD). 


\section{Free acidity, $\mathrm{pH}$, lactone acidity, and total acidity}

In this study, free acidity, $\mathrm{pH}$, lactone acidity and total acidity measurements were performed according to IHC guidelines (Bogdanov, 2002).

\section{Proline content}

Proline content was determined by the ninhydrin method. Proline content was expressed relative to honey mass (Bogdanov, 2002).

\section{Diastase activity}

Diastase activity was measured as reported by Bogdanov (2002).

\section{Sugar content}

In this experiment, $5 \mathrm{~g}$ of honey was dissolved in water and transferred to a $100 \mathrm{ml}$ volumetric flask containing $25 \mathrm{ml}$ of methanol; the volume was adjusted to $100 \mathrm{ml}$ with water (Al et al., 2009). The solution was passed through a $0.45-\mu \mathrm{m}$ filter (VWR International, USA) and stored in vials at $4{ }^{\circ} \mathrm{C}$. Sugar content was determined in an HPLC system equipped with a refractive index (RI) detector (Hitachi model L-2490, Japan). Sugar separation was performed in a Merck amino-bonded high purity silica column (LiChroCART 250-4; particle size diameter of $5 \mu \mathrm{m}$ ) equipped with a guard column (Merck LiChroCART 4-4) maintained at $30{ }^{\circ} \mathrm{C}$. The HPLC pump, autosampler, column oven and RI detector were monitored using an EZChrom Elite system. The mobile phase consisted of 75\% HPLC grade acetonitrile (Panreac, Barcelona, Spain) in water. The injection volume of the samples was $10 \mathrm{~mL}$ with a flow rate of $1.3 \mathrm{ml} / \mathrm{min}$. Sample peaks were identified by comparing their retention times with those of standards. Additionally, the samples were spiked with standards to verify the identity of the chromatographic peaks. The average peak areas of triplicate injections were used for peak quantification. A calibration curve was generated for each sugar using standard solutions $(0.1-40 \mathrm{mg} /$ $\mathrm{ml})$. The samples in crystallized form were liquefied in a $40{ }^{\circ} \mathrm{C}$ water bath. Fructose and glucose standards were purchased from Sigma (St. Louis, MO); other standards consisted of D-(+)-turanose and D-(+)-melizitose (AppliChem, Darmstadt, Germany), D-trehalose (Acros Organics, NJ), D-(+)-maltose (Fisher BioReagents, NJ), and D$(+)$-saccharose (Riedel-de Haën Sigma-Aldrich Laborchemikalien $\mathrm{GmbH}$, Seelze, Germany).

\section{Hydroxymethylfurfural content}

Hydroxymethylfurfural (HMF) content was determined according to IHC guidelines (Bogdanov, 2002).

\section{Total phenol content}

Total phenol content was determined by a modification of the Folin-Ciocalteau method (Singleton \& Rossi,
1965); results were expressed as $\mathrm{mg}$ gallic acid (Acros Organics, NJ) equivalents (GAE)/l00 g honey. Briefly, $5 \mathrm{~g}$ of honey was mixed with $50 \mathrm{ml}$ of distilled water and passed through a qualitative filter. A volume of the filtrate $(500 \mathrm{ml})$ was mixed with $2.5 \mathrm{ml}$ of $0.2 \mathrm{~N}$ FolinCiocalteu reagent (Merck, Darmstadt, Germany) for $5 \mathrm{~min}$ and with $2 \mathrm{ml}$ of $75 \mathrm{~g} / \mathrm{l} \mathrm{Na} \mathrm{CO}_{3}$ (Pronalab, Lisboa, Portugal). All samples were incubated for $2 \mathrm{~h}$ in the dark at room temperature and their absorbance was measured at $760 \mathrm{~nm}$. The blank contained water instead of honey. A standard curve was generated from a stock solution of gallic acid $(\mathrm{I} \mathrm{mg} / \mathrm{ml})$ diluted to different concentrations $(8-250 \mathrm{mg} / \mathrm{ml})$.

\section{Honey color}

Color was determined by measuring the absorbance of aqueous solutions ( $10 \mathrm{~g}$ honey in $20 \mathrm{ml}$ water) at $635 \mathrm{~nm}\left(\mathrm{~A}_{635}\right)$ in a Shimadzu spectrophotometer (Naab, Tamame, \& Caccavari, 2008). Table 2 shows the sample colors, absorbance measurements, and $\mathrm{mm}$ Pfund values using the following algorithm, $\mathrm{mm}$ Pfund $=$ $-38.7+371.39 \times \mathrm{A}_{635}$.

\section{Microbiological analysis}

Previously to the evaluation of the antibacterial activity of honey samples the microbiological quality was determined as described previously (Miguel, Antunes, Aazza, Duarte, \& Faleiro, 2013a). The microbiological parameters included the counts of aerobic mesophilic bacteria (NP-4405: 2002), yeasts and molds (ISO 21527-2:2008), Enterobacteriaceae (ISO 21528-2:2004) and sulfite-reducing Clostridium spp. (ISO I52 |3:2003). The used culture media were purchased from Oxoid (Basingstoke, Hampshire, UK) and Biokar (Paris, France). Ten grams of each sample were transferred to $90 \mathrm{ml}$ of peptone water (Oxoid) and homogenized. Decimal dilutions were prepared using the same diluent. The detection procedure for Salmonella spp. was done according to the international standard ISO 6579:2002. The microbiological determinations were done in triplicate.

\section{Microorganisms}

The microorganisms used in the present study are indicated in Table I. The bacterial cultures were recovered from $-80^{\circ} \mathrm{C}$ and grown in the appropriate medium. The $S$. aureus, MRSA and $P$. aeruginosa strains were grown in Brain Heart Infusion (Biokar, Paris, France) and incubated at $37^{\circ} \mathrm{C}$.

\section{Antibacterial activity}

The determination of the antibacterial activity was evaluated according to the previously described (Miguel et al., $2013 \mathrm{~b}$ ). Prior to each assay the bacterial cells were grown in fresh agar plates to obtain an exponential 
Table I. Microorganisms used in the study.

\begin{tabular}{lll}
\hline Bacteria & Origin & Source \\
\hline Staphylococcus aureus ATCC 6538 & Wound & American Type Culture Collection \\
Staphylococcus aureus meticillin resistant 4 (MRSA 4) & Clinical & Universidade do Algarve, CBMR, Portugal \\
Staphylococcus aureus meticillin resistant I2 (MRSA 12) & Clinical & Universidade do Algarve, CBMR, Portugal \\
Pseudomonas aeruginosa DSM 939 & Animal room water bottle German Collection of Microorganisms and Cells \\
\hline
\end{tabular}

culture. The inoculum was prepared from the previous culture, by suspending the bacterial cells in BHI broth supplemented with the appropriate concentration of honey and a volume of $20 \mu \mathrm{l}$ of this bacterial suspension was used to inoculate a microplate well with $\mid 80 \mu l$ of the same medium. The incubation of the microplate was done at $37{ }^{\circ} \mathrm{C}$ during $15 \mathrm{~h}$ and the growth was monitored by measurement of the optical density at $600 \mathrm{~nm}$ $\left(O D_{600} \mathrm{~nm}\right)$. The viability of cells, at the end of the growth experiment was evaluated by plating $30 \mu \mathrm{l}$ of the culture in each well in $\mathrm{BHI}$ agar. The antibiotic chloramphenicol $(30 \mu \mathrm{g} / \mathrm{ml})$ and hydrogen peroxide $(0.5 \% \mathrm{v} / \mathrm{v})$ were used as control. Three independent experiments were done. The percentage of inhibition of the bacterial growth and percentage of growth was determined as described by Patton, Barrett, Brennan, and Moran (2006).

\section{Inhibition of adherence}

The estimation of the inhibition of the bacterial adherence by the tested honey samples was done according to Adrião et al. (2008). Bacterial suspensions of S. aureus, MRSA and $P$. aeruginosa $\left(\mathrm{OD}_{600 \mathrm{~nm}}=0.4-0.5\right)$ in $\mathrm{BHI}$ supplemented with $25 \% \mathrm{w} / \mathrm{v}$ or $12.5 \%$ of honey were allowed to adhere for $2 \mathrm{~h}$. Non-adherent cells were removed by washing the wells twice with sterile phosphate-buffered saline (PBS). Wells were air-dried and adherent cells heat-fixed at $80{ }^{\circ} \mathrm{C}$ for $30 \mathrm{~min}$ and stained with $0.1 \%$ crystal violet (Merck, Germany). After the dissolution of the stain by addition of ethanol-acetone $(80: 20)$ the $\mathrm{OD}_{595} \mathrm{~nm}$ was determined with a microplate reader (Tecan Infinite M200 Model, Austria). A commercial solution of chlorhexidine $(0.2 \% \mathrm{w} / \mathrm{v})$ was used as reference.

\section{Impact of honey on virulence}

The impact of the different honey samples on bacterial virulence was evaluated using the larvae model of the greater wax moth G. mellonella L. (Lepidoptera: Pyralidae) as previously described (Schrama, Helliwell, Neto, \& Faleiro, 2013). G. mellonella was reared during the first and second instars on pollen and wax and afterward on an artificial diet composed of a mixture of glycerol, honey, water, dry dog food and wheat bran. The development of the insects was accomplished in the dark at $30 \pm \mathrm{I}{ }^{\circ} \mathrm{C}$. Larvae used on this experiment weighted between 250 and $350 \mathrm{mg}$. Each $S$. aureus or $P$. aeruginosa culture $\left(10^{8} \mathrm{CFU} / \mathrm{ml}\right)$ treated during $2 \mathrm{~h}$ with honey was centrifuged at $2,790 \times \mathrm{g}$ for $5 \mathrm{~min}$ at $4{ }^{\circ} \mathrm{C}$. The bacterial cells were resuspended in I $\mathrm{ml}$ of sterile PBS. Ten larvae were infected with $10 \mu$ of the initial suspension $\left(10^{6} \mathrm{CFU}\right)$ by injection on the second right proleg using a microsyringe $(50 \mu \mathrm{l}$, Sigma, Madrid, Spain). Before injection, larvae were disinfected on the surface with ethanol at $70 \%(\mathrm{v} / \mathrm{v})$. Larvae were placed in sterile Petri dishes at $37{ }^{\circ} \mathrm{C}$ during 5 days. Death was checked each $24 \mathrm{~h}$, and considered when no response to touch was observed. Ten larvae were infected with $10 \mu l$ of the bacterial culture not treated with honey as positive control and ten larvae were infected with $10 \mu \mathrm{l}$ of PBS as negative control.

\section{Anti-inflammatory activity}

The anti-inflammatory activity of the analyzed honey was evaluated by measuring the activity of the enzymes hyaluronidase and lipoxygenase.

Hyaluronidase activity was determined spectrophotometrically by measuring the amount of $\mathrm{N}$-acetylglucosamine formed from sodium hyaluronate (Sahasrabudhe and Deodhar, 20l0). One hundred $\mathrm{ml}$ of bovine hyaluronidase $(7,900$ units $/ \mathrm{ml})$ dissolved in $0.1 \mathrm{M}$ phosphate buffer $(\mathrm{pH} 3.6)$ was mixed with $100 \mu l$ of a designated concentration of samples and then incubated in a water bath at $37^{\circ} \mathrm{C}$ for 20 min. Fifty $\mu$ l of $12.5 \mathrm{mM}$ calcium chloride was added to the reaction mixture, and then the mixture was incubated in a water bath at $37{ }^{\circ} \mathrm{C}$ for $20 \mathrm{~min}$. Following $250 \mu \mathrm{l}$ of sodium hyaluronate $(1.2 \mathrm{~g} / \mathrm{l})$ dissolved in $0.1 \mathrm{M}$ phosphate buffer $(\mathrm{pH} 3.6)$, were added and the tubes were re-incubated at $37{ }^{\circ} \mathrm{C}$ for $40 \mathrm{~min}$. The reaction was continued by the addition of $50 \mu \mathrm{l}$ of sodium hydroxide $(0.4 \mathrm{M})$ and 100 $\mu$ l of sodium borate $(0.2 \mathrm{M})$. The mixture was incubated at $100{ }^{\circ} \mathrm{C}$ for $3 \mathrm{~min}$. After cooling to room temperature, $1.5 \mathrm{ml}$ of dimethylaminobenzeldehyde solution (4 g of p-dimethylaminobenzaldehyde dissolved in $350 \mathrm{ml}$ of $100 \%$ acetic acid and $50 \mathrm{ml}$ of $10 \mathrm{~N}$ hydrochloric acid) was added to the reaction mixture. Two hundred microliters of the final mixture were distributed per 96 microplate well and the OD $\left(O D_{586} \mathrm{~nm}\right)$ reading was done in a Tecan Infinite M200 Model (Austria).

The activity of lipoxygenase was determined according to $\mathrm{Wu}$ (1996). A volume of $10 \mu \mathrm{l}$ of the honey sample was mixed with $960 \mu \mathrm{l}$ of borate buffer (2 M, pH 9.0) and 
$5 \mu \mathrm{l}$ of the lipoxygenase enzyme $(8,000 \mathrm{U} / \mathrm{mg})$ was added. The reaction was initiated by adding $20 \mu \mathrm{l}$ of linoleic acid $(2.8 \mathrm{~g} / \mathrm{l})$ and the $\mathrm{OD}\left(\mathrm{OD}_{234} \mathrm{~nm}\right)$ reading was done immediately. A solution of eugenol $(1 \% \mathrm{v} / \mathrm{v})$ was used as positive control. The activity of the enzyme in the absence of any inhibitor was used as negative control. Ten dilutions I:2 were done for each sample. The final concentration of honey was $15 \mathrm{~g} / \mathrm{l}$. Measurements were done in triplicate for each sample.

\section{Statistical analysis}

The significant differences on the physicochemical parameters, antibacterial and anti-inflammatory activities, and inhibition of the adherence and virulence of the different honey samples were determined through the SPSS 20.0 program (Inc., Chicago IL, USA) and using the Tukey post hoc test.

\section{Results and discussion}

\section{Physicochemical characterization of honey samples}

The results of the physicochemical parameters determined in the samples of honey are shown in Table 2. All samples complied with the limits established for floral honeys (EU Council, 2002; DR, 2003). Higher pH values were observed for strawberry tree honey in comparison to citrus, such difference it was previously reported by Aazza, Lyoussi, Antunes, and Miguel (2013).

Acidity, which results from the presence of gluconic, pyruvic, malic and citric acids, in equilibrium with lactones, esters and inorganic ion, affects the flavor and aroma of honey (Isla et al., 20II). Aazza et al. (20I3) reported similar free acidities for strawberry tree and citrus honeys, in contrast to those found in the present work, in which citrus honey had higher free acidity (Table 2). Nevertheless, the lactone acidity was significantly lower in strawberry tree honey than in citrus honey, as described by Aazza et al. (2013) for honeys of the same floral origin. Free acidity values being inferior to 40 or $50 \mathrm{mEq} / \mathrm{kg}$, as required by the Codex Alimentarius (200I) or EU Council (2002), respectively, indicate the absence of undesirable fermentations. Moisture content inferior to $20 \%$, as imposed by Codex Alimentarius (200I), prevents the growth of molds on honey surface, and therefore avoiding fermentation during storage (Mendes, Brojo Proença, Ferreira, \& Ferreira, 1998).

Electrical conductivity, a parameter closely related with the concentrations of minerals, organic acids and proteins, is useful for differentiating between nectar honey and honeydew (Bogdanov, Ruoff, \& Oddo, 2004; Terrab, González, Díez, \& Heredia, 2003a). For nectar honeys, this parameter cannot exceed $800 \mu \mathrm{S} / \mathrm{cm}$, except for strawberry tree, bell heather, ling heather, lime, eucalyptus, manuka or jelly bush, which values can be superior to that of $800 \mu \mathrm{S} / \mathrm{cm}$. In this way, the values of electrical conductivity of honeys analyzed in the present work were within the ranges permitted by law.

From a quantitative point of view, proline is the most important amino acid in honey, although other amino acids can be found: lysine, histidine, arginine, aspartic acid, threonine, and serine among others (Terrab, Diez, \& Heredia, 2003b). Proline is originated from bee salivary secretions during the conversion of nectar into honey and concentrations lower than $183 \mathrm{mg} / \mathrm{kg}$ may indicate an inferior quality of honey and suspicion of an adulteration (Islam et al., 20/2). In the present work, the concentrations of proline were always higher than that value (Table 2), and also superior to those

Table 2. Physicochemical characterization of the honey samples.

\begin{tabular}{|c|c|c|c|}
\hline Analysis & Citrus & Lavender & Strawberry tree \\
\hline $\begin{array}{l}\mathrm{pH} \\
\text { Free acidity }(\mathrm{mEq} / \mathrm{kg}) \\
\text { Lactone acidity }(\mathrm{mEq} / \mathrm{kg}) \\
\text { Total acidity }(\mathrm{mEq} / \mathrm{kg}) \\
\text { Moisture }(\%) \\
\text { Conductivity }(\mu \mathrm{S} / \mathrm{cm}) \\
\text { Proline }(\mathrm{mg} / \mathrm{kg}) \\
\text { Diastase }(\mathrm{Shade} \text { units } / \mathrm{g}) \\
\text { HMF }(\mathrm{mg} / \mathrm{kg}) \\
\text { Color }(\mathrm{Pfund} \text { scale, } \mathrm{mm}) \\
\text { Phenols }(\mathrm{mg} \mathrm{GAE} / \mathrm{l} 00 \mathrm{~g}) \\
\text { Fructose }(\mathrm{g} / \mathrm{kg}) \\
\text { Glucose }(\mathrm{g} / \mathrm{kg}) \\
\text { Fructose }+\mathrm{glucose}(\mathrm{g} / \mathrm{kg}) \\
\text { Sucrose }(\mathrm{g} / \mathrm{kg}) \\
\text { Turanose }(\mathrm{g} / \mathrm{kg}) \\
\text { Maltose }(\mathrm{g} / \mathrm{kg}) \\
\text { Trehalose }(\mathrm{g} / \mathrm{kg})\end{array}$ & $\begin{array}{c}3.6 \pm 0.0^{\mathrm{c}} \\
22.4 \pm 0.7^{\mathrm{a}} \\
16.9 \pm 0.4^{\mathrm{a}} \\
39.3 \pm 1.0^{\mathrm{a}} \\
19.5 \pm 0.1^{\mathrm{a}} \\
413.3 \pm 4.0^{\mathrm{b}} \\
642.8 \pm 6.8^{\mathrm{a}} \\
6.8 \pm 0.6^{\mathrm{c}} \\
9.9 \pm 0.3^{\mathrm{a}} \\
23.3 \pm 1.5^{\mathrm{b}}(\text { white }) \\
57.3 \pm 0.9^{\mathrm{b}} \\
351.9 \pm 4.1^{\mathrm{c}} \\
292.5 \pm 4.6^{\mathrm{a}} \\
644.4 \pm 4.9^{\mathrm{b}} \\
4.1 \pm 0.1^{\mathrm{a}} \\
22.6 \pm 0.5^{\mathrm{a}} \\
27.8 \pm 0.6^{\mathrm{a}} \\
11.0 \pm 0.4^{\mathrm{b}}\end{array}$ & $\begin{array}{c}3.8 \pm 0.0^{\mathrm{b}} \\
18.3 \pm 0.7^{\mathrm{b}} \\
11.9 \pm 0.4^{\mathrm{b}} \\
30.2 \pm 1.0^{\mathrm{b}} \\
19.4 \pm 0.1^{\mathrm{a}} \\
319.9 \pm 4.0^{\mathrm{c}} \\
471.6 \pm 6.8^{\mathrm{b}} \\
13.6 \pm 0.6^{\mathrm{b}} \\
10.3 \pm 0.3^{\mathrm{a}} \\
26.9 \pm 1.5^{\mathrm{b}}(\text { white) } \\
48.8 \pm 0.9^{\mathrm{c}} \\
396.9 \pm 4.1^{\mathrm{a}} \\
267.4 \pm 3.4^{\mathrm{b}} \\
664.4 \pm 4.9^{\mathrm{a}} \\
3.8 \pm 0.1^{\mathrm{b}} \\
20.4 \pm 0.5^{\mathrm{b}} \\
28.6 \pm 0.6^{\mathrm{a}} \\
12.1 \pm 0.4^{\mathrm{a}}\end{array}$ & $\begin{array}{c}4.1 \pm 0.0^{\mathrm{a}} \\
15.0 \pm 0.7^{\mathrm{c}} \\
7.8 \pm 0.5^{\mathrm{c}} \\
22.8 \pm 0.9^{\mathrm{c}} \\
19.2 \pm 0.1^{\mathrm{b}} \\
1491.7 \pm 4.5^{\mathrm{a}} \\
465.1 \pm 7.6^{\mathrm{b}} \\
16.3 \pm 0.6^{\mathrm{a}} \\
7.0 \pm 0.2^{\mathrm{b}} \\
63.0 \pm 1.7^{\mathrm{a}} \text { (light amber) } \\
101.1 \pm 1.0^{\mathrm{a}} \\
375.4 \pm 4.6^{\mathrm{b}} \\
263.4 \pm 3.4^{\mathrm{b}} \\
639.3 \pm 4.3^{\mathrm{b}} \\
3.3 \pm 0.1^{\mathrm{c}} \\
18.8 \pm 0.4^{\mathrm{c}} \\
27.7 \pm 0.7^{\mathrm{a}} \\
10.3 \pm 10.3^{\mathrm{b}}\end{array}$ \\
\hline
\end{tabular}

Notes: Data are the mean of three independent experiments \pm standard deviation. In each row the values with different letters are significantly different $(p<0.05)$ 
already reported by us for Portuguese honeys of the same floral origin (Aazza et al., 2013).

The diastase activity and the HMF content are known as parameters representative of honey freshness. Inadequate storage and/or processing conditions are responsible for the decrease of diastase activity and an increase of HMF content. The enzyme is susceptible to heating and storage factors, diminishing the activity. After heating honey it is produced HMF through acidcatalyzed dehydration of hexoses (fructose, glucose) (Belitz \& Grosch, 1999). A minimal of 8 Schade units/g of honey is required by the European legislation (EU, 2002), nevertheless for citrus honey, a minimal of 3 Schade units/g is allowed, provided that HMF content does not exceed $15 \mathrm{mg} / \mathrm{kg}$. In this way, the values found for diastase activity and HMF content fulfill the limits required by the EU Council (2002) for fresh honey.

The presence of compounds with double bonds (polyphenols, flavonoids, terpenes, carotenoids and Maillard reaction products) is responsible for the honey color, since such compounds absorb light in the visible range $\left(A_{400 \mathrm{~nm}}-\mathrm{A}_{700 \mathrm{~nm}}\right)$ (Borrelli, Visconti, Mennella, Anese, \& Fogliano, 2002; Brudzynski \& Kim, 20I I; Naab et al., 2008). Honey color is related to the plant origin and storage conditions ( $\mathrm{Naab}$ et al., 2008). Strawberry tree honey was light amber whereas citrus and lavender honeys were white. The colors of strawberry tree and citrus honeys are according to those previously reported for commercial honeys from Portugal of the same floral origins (Aazza et al., 20l3). Lavender honey in the present work was slightly lighter than that reported for lavender honey previously reported (light extra amber) (Aazza et al., 2013).

Phenol content ( $\mathrm{mg}$ of gallic acid equivalent/100 $\mathrm{g}$ of honey) ranged from 48.8 in lavender honey to 101.1 in strawberry tree honey (Table 2). Such results were similar to those reported for commercial honeys from Portugal with the same floral origin (Aazza et al., 20l3). However, citrus honeys from other locations had different amounts of phenols (Rodríguez, Mendoza, Iturriga, \& Castaño-Tostado, 2012; Rosa et al., 201I). Others and ours findings suggest that beyond the floral origin, geographical origin is also important in the phenol content in honey samples.

Fructose and glucose were the most important sugars in the samples, as expected (Table 2). Citrus honey had the lowest concentration of fructose and the highest amount of glucose. The opposite was verified in lavender honey (Table 2). In all samples, the total fructose and glucose content was superior to the minimum permissible concentration (60\%) (Codex Alimentarius, 200 I; EU, 2002). Sucrose content was also within the permissible limits (no more than 5\%) (Codex Alimentarius, 200I; EU, 2002).

The levels of turanose, maltose and trehalose are similar to those already reported for commercial honey samples of the same floral origin (Aazza et al., 20/3). Melezitose was absent, which confirm that samples are blossom honeys. High concentrations of that trisaccharide are characteristics of honeydew honeys (Bogdanov et al., 2004).

The tested honey samples were negative for all the microbiological parameters tested evidencing an excellent microbiological quality. Honeys are characterized by low levels of microbial contamination (Kačániová et al., 2009; Gomes et al., 2010; Estevinho et al., 2012) either by compliance with harvesting and manufacturing standards or due to the antimicrobial activity. It is possible that the absence of microbial contamination of the analyzed honey samples resulted from both features.

\section{Antibacterial activity}

The susceptibility of $S$. aureus, MRSA strains and $P$. aeruginosa to the tested honey samples is shown in Table 3. At the concentrations below $12.5 \% \mathrm{w} / \mathrm{v}(6.25$ and $3.13 \% \mathrm{w} / \mathrm{v}$ ) all tested honeys showed no growth inhibition of the tested strains therefore is shown the results for the inhibitory concentrations $(12.5,25$ and $50 \% \mathrm{w} / \mathrm{v})$. The inhibition of the growth of all tested strains was concentration dependent for all honey samples analyzed.

The growth of MRSA strains was inhibited near $100 \%$ by lavender honey at $50 \% \mathrm{w} / \mathrm{v}$. In contrast at $25 \%$ $w / v$ the strawberry tree honey showed the highest $(p<0.05)$ inhibitory activity. The inhibitory activity of the antibiotic chloramphenicol was similar $(p<0.05)$ to the action of the tested honeys at $50 \% \mathrm{w} / \mathrm{v}$ (Table 3 ). At $12.5 \% \mathrm{w} / \mathrm{v}$ the citrus honey promoted the growth of S. aureus ATCC 6538. A promotion of growth, at this same concentration was also observed for lavender honey, which promoted the growth of S. aureus ATCC 6538, and as well the growth of the MRSA strains (Table 3). The antistaphylococcal activity of the honeys was not correlated with phenol or acidity (for phenols a $r$-value of $-0.333, p=0.580$ and for acidity a $r$-value of $0.233, p=0.579)$.

The citrus, lavender and strawberry tree honey at $50 \% \mathrm{w} / \mathrm{v}$ showed a similar $(p<0.05)$ inhibition activity against $P$. aeruginosa. At 12.5 and $25 \%$ the citrus honey showed the highest inhibitory activity against $P$. aeruginosa achieving an inhibition \% of $20.32 \pm 0.17$ and 39.41 \pm 0.39 , respectively. The inhibitory action of $\mathrm{H}_{2} \mathrm{O}_{2}$ was similar $(p<0.05)$ to the tested honeys at $50 \%$. In contrast the antibiotic chloramphenicol showed a lower inhibitory $(p<0.05)$ in comparison to the tested honeys at $50 \%$ (Table 2). The anti-pseudomonal activity of the tested honeys (at $25 \% \mathrm{w} / \mathrm{v}$ ) was positively correlated with the acidity ( $r$-value of $0.744, p<0.05$ ).

The susceptibility of MRSA and $P$. aeruginosa strains to different honeys have been reported and the concentration of honey that causes significant growth reduction was similar to the found in other studies (AlvarezSuarez et al., 2010; Sherlock et al., 2010; Tan et al., 2009). The high susceptibility of $S$. aureus to honey phenols has been reported (Alvarez-Suarez et al., 2010; 
Table 3. Antibacterial activity of the different honeys.

\begin{tabular}{lccccc}
\hline & & \multicolumn{4}{c}{ Microorganism (\% inhibition \pm SD) } \\
\cline { 2 - 6 } Honey & Concentration \% w/v & S. aureus ATCC 6538 & MRSA 4 & MRSA I2 & Pseudomonas aeruginosa DSM939 \\
\hline Citrus & 50 & $98.92 \pm 0,70^{\mathrm{a}}$ & $94.85 \pm 0.55^{\mathrm{a}}$ & $93.56 \pm 0.16^{\mathrm{a}}$ & $98.90 \pm 0.16^{\mathrm{a}}$ \\
& 25 & $20.54 \pm 0.52^{\mathrm{b}}$ & $20.17 \pm 1.06^{\mathrm{b}}$ & $30.45 \pm 1.59^{\mathrm{b}}$ & $39.41 \pm 0.39^{\mathrm{b}}$ \\
& 12.5 & $111.06 \pm 9.83^{*}$ & $9.24 \pm 0.69^{\mathrm{c}}$ & $6.27 \pm 0.72^{\mathrm{c}}$ & $20.32 \pm 0.17^{\mathrm{c}}$ \\
Lavender & 50 & $82.10 \pm 0.95^{\mathrm{a}}$ & $99.19 \pm 0.53^{\mathrm{a}}$ & $97.37 \pm 0.18^{\mathrm{a}}$ & $98.17 \pm 0.77^{\mathrm{a}}$ \\
& 25 & $13.28 \pm 0.42^{\mathrm{b}}$ & $18.30 \pm 0.93^{\mathrm{b}}$ & $23.22 \pm 0.80^{\mathrm{b}}$ & $36.83 \pm 1.10^{\mathrm{b}}$ \\
Strawberry tree & 12.5 & $103.04 \pm 2.69^{*}$ & $97.38 \pm 6.98^{*}$ & $103.05 \pm 1.98^{*}$ & $19.20 \pm 0.44^{\mathrm{c}}$ \\
& 50 & $81.52 \pm 0.93^{\mathrm{a}}$ & $91.31 \pm 1,01^{\mathrm{a}}$ & $94.40 \pm 0.56^{\mathrm{a}}$ & $97.56 \pm 0.92^{\mathrm{a}}$ \\
& 25 & $21.52 \pm 0.86^{\mathrm{b}}$ & $26.50 \pm 0.42^{\mathrm{b}}$ & $35.82 \pm 0.70^{\mathrm{b}}$ & $25.95 \pm 0.25^{\mathrm{b}}$ \\
Chloramphenicol & 12.5 & $6.63 \pm 0.15^{\mathrm{c}}$ & $7.54 \pm 0.47^{\mathrm{c}}$ & $24.68 \pm 0.99^{\mathrm{c}}$ & $5.42 \pm 0.07^{\mathrm{c}}$ \\
$(30 \mu \mathrm{ml})$ & & & & & $68.58 \pm 2.93$ \\
$\mathrm{H}_{2} \mathrm{O}_{2}(0.5 \% \mathrm{v} / \mathrm{v})$ & & $84.54 \pm 1.82$ & $96.21 \pm 0.50$ & $84.09 \pm 0.85$ & $98.73 \pm 2.59$ \\
\hline
\end{tabular}

Notes: ${ }^{*}$ - growth promotion and $\mathrm{NI}-$ no inhibition. Data are mean of three independent experiments \pm standard deviation. For each honey the values in the column with different letters are significantly different $(p<0.05)$.

Estevinho, Pereira, Moreira, Dias, \& Pereira, 2008). Although the correlation of $S$. aureus susceptibility to honeys with acidity has been reported (Bogdanov, 1997) in our study this was not observed. Such result may be strain dependent. The lower susceptibility of $P$. aeruginosa to phenolic extracts has been reported (AlvarezSuarez et al., 2010; Estevinho et al., 2008). The antipseudomonal activity of honeys seem to be associated to acidity and this will be linked to the cellular effects of the organic acids present in the honeys, which affect the $\mathrm{pH}$ homeostasis, injure the cell membrane and impair crucial metabolic pathways (Faleiro, 2012).

The results observed in our study evidence the potential therapeutic value of the tested honey samples against bacterial pathogens frequently found in wound infections.

\section{Inhibition of adherence}

The inhibitory activity of the different honeys on the adherence ability of $S$. aureus, MRSA and P. aeruginosa was evaluated and is illustrated in Figure I. The adherence ability of S. aureus ATCC 6538 was significantly affected by the citrus honey $(p<0.05)$ whereas strawberry tree and lavender honey showed similar $(p<0.05)$ adherence inhibition (Figure I). The tested honeys showed a different effect on the adherence inhibition of the MRSA strains. The MRSA 4 adherence was equally impaired $(p<0.05)$ by the three honeys samples. In contrast, the MRSA 12 adherence ability was highly affected by the strawberry tree honey $(p<0.05)$ (Figure I). The adherence capacity of $P$. aeruginosa was highly reduced by the lavender honey $(p<0.05)$ followed by the citrus and strawberry tree honey (Figure I).
The clorhexidine did not inhibit the adherence of the $S$. aureus and the MRSA strains instead stimulated their adherence ability (Figure I). In contrast, the adherence ability of $P$. aeruginosa was affected by clorhexidine but in a less extent $(p<0.05)$ in comparison to the tested honeys (Figure I).

The ability of honey to inhibit adherence or disrupt biofilm of oral bacteria and wound bacteria, such as Streptococcus pyogenes have been investigated (Badet \& Quero, 20II; Maddocks, Lopez, Rowlands, \& Cooper, 2012; Nassar, Li, \& Gregory, 20I2). This honey propriety constitutes a critical tool not only to inhibit the growth of bacterial pathogens but also to control an important aspect of the bacterial physiology, which is their ability to adhere and form biofilm, either in biotic or abiotic surfaces. The major problem of this bacterial community form of life is the acquisition of resistance by the sessile cells (biofilm cells), and their elimination becomes very difficult (see review by Høiby, Bjarnsholt, Givskov, Molin, \& Ciofu, 20I0a and by Paraje, 20II). In our study at $25 \% \mathrm{w} / \mathrm{v}$, strawberry honey showed a significant anti-biofilm activity against the MRSA strains, and all honey samples, at the same concentration were effective in inhibiting the adherence ability of $P$. aeruginosa, a very challenging biofilm producer (Høiby, Ciofu, \& Bjarnsholt, 20l0b).

Manuka honey has been reported as being effective in the eradication of biofilm produced by $S$. aureus, $P$. aeruginosa and S. pyogenes strains (Lu et al., 20l4; Maddocks et al., 2013), although some studies have found that manuka honey resistant isolates exhibited increased biofilm forming capacity, despite with slower growing ability than the wild type strains (Camplin \& Maddocks, 2014). This same team also found that such resistant isolates to manuka honey also demonstrated increased 

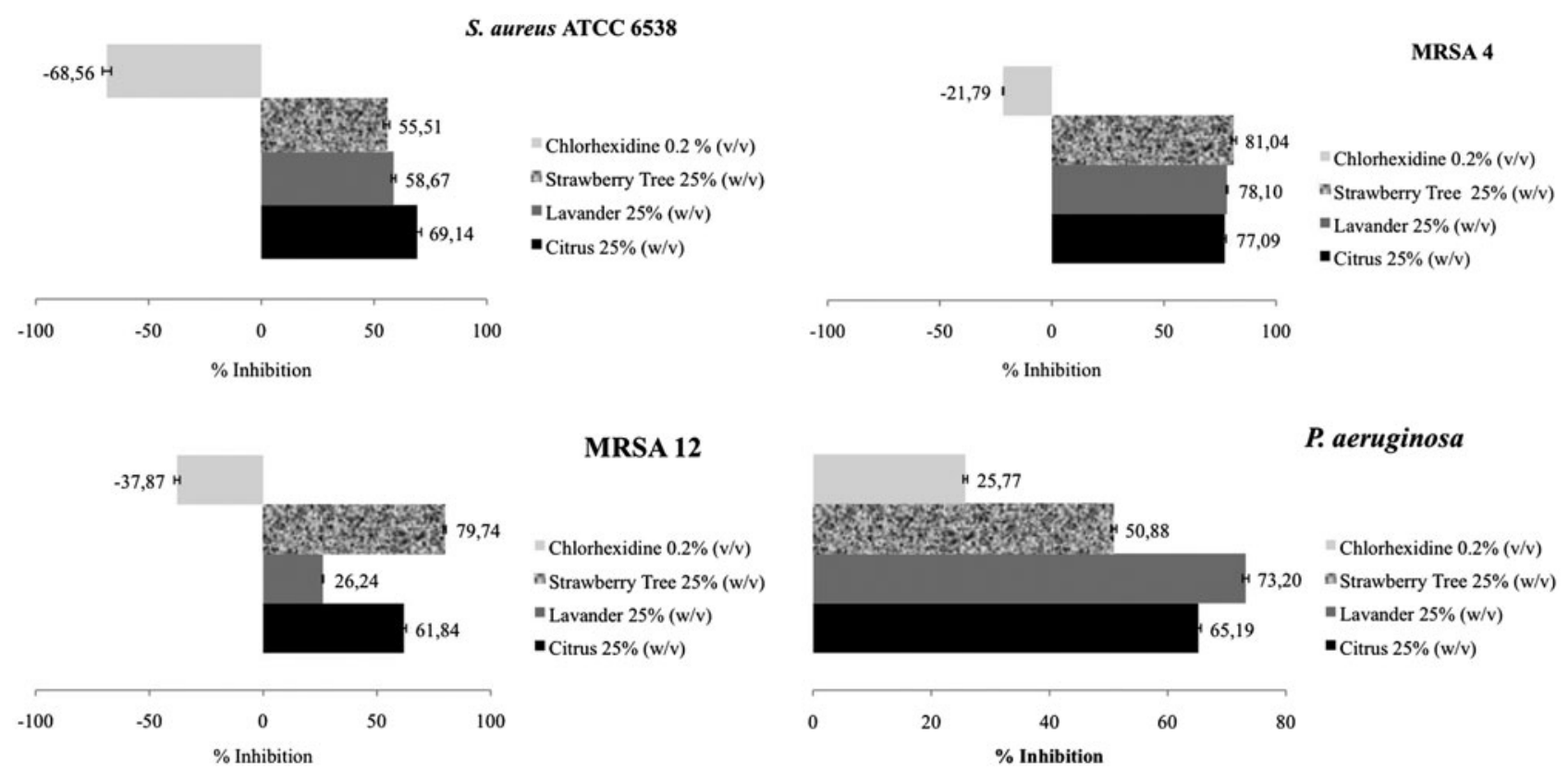

P. aeruginosa

"Chlorhexidine $0.2 \%$ (v/v) a Strawberry Tree $25 \%$ (w/v) - Lavander $25 \%$ (w/v) - Citrus $25 \%$ (w/v)

Figure I. The effect of the different honeys on bacterial adherence.

Note: Data are the mean of three independent experiments $(n=9)$. Error bars represent the standard deviation.

resistance to treatment with some antibiotics (Camplin \& Maddocks, 20l4).

The concentrations of honeys to prevent biofilm formation may be the same for those found for inhibiting planktonic growth (Camplin \& Maddocks, 20I4), higher (Maddocks et al., 20I2, 20I3) or lower (Lee et al., 20I2). In this case, the authors reported that honeys at low concentrations $(0.5 \%)$ were able to reduce biofilm formation of enterohemorrhagic Escherichia coli OI57: $\mathrm{H} 7$ without inhibiting the growth of planktonic cells. In the present work, honeys at $25 \%$ had higher capacity for preventing the formation of biofilms than for inhibiting the growth of planktonic cells (Figure I and Table 3). Lower concentrations (12.5\%) were even promoters of the planktonic cell growth, particularly for citrus and lavender honeys (Table 3). This is a concern, because the application of honey at subinhibitory concentration may promote the cell growth instead of its inhibition. A dilution of honey may easily occur in those cases in which there is wound exudates or other secretions from the wound surface (Halstead et al., 2016).

The prevention of biofilm formation mediated by honey has been attributed to several compounds, alone or combined, including fructose, glucose, phenols, hydrogen peroxide, dicarbonyl methylglyoxal, or to the their characteristic physical properties $(\mathrm{pH}$ and hyperosmolarity) (Halstead et al., 2016; Lu et al., 2014). In short, there is not yet clarified to which compounds may be attributed to the ability of preventing the formation of biofilm or its disruption.

Bacterial biofilm formation is linked to the quorumsensing system (QS), a cell-cell communication system that modulates gene expression and works in a cell density dependent mode (Davies et al., 1998). In staphylococci, the QS mechanism comprises the accessory gene regulator (agr) locus that controls the production of a small autoinducing signal peptide (AIP) (see the review by Otto, 2013). In contrast the QS molecules produced by the Gram negative $P$. aeruginosa are acyl homoserine lactones and the 2-heptyl-3-hydroxy-4quinolone (also named PQS as Pseudomonas quinolone signal) (Schuster, Lostroh, Ogi, \& Greenberg, 2003). How honey impairs biofilm formation by disrupting the QS system in S. aureus and P. aeruginosa needs further investigation.

\section{The impact of honey on virulence}

The influence of the exposure of the bacterial strains S. aureus, MRSA 4 and MRSA 12 on virulence was evaluated using the $G$. mellonella model. The results are illustrated in Figure 2.

The survival of the larvae injected with $S$. aureus ATCC 6538 previously treated with any of the tested honeys were significantly higher $(p<0.05)$ during the five days of observation in comparison to the larvae injected with bacterial cells not treated with honey (Figure 2). The same result was observed for the MRSA strains for which the survival of the larvae injected with bacterial cells formerly treated with honey samples survived significantly better $(p<0.05)$. The influence of the exposure of $P$. aeruginosa cells to the tested honeys at 25 and $50 \%$ $\mathrm{w} / \mathrm{v}$ did not affect the virulence potential of the bacterial cells. The survival of the larvae injected with bacterial cells formerly treated with each honey was similar to the control cells reaching a null survival after $24 \mathrm{~h}$. 

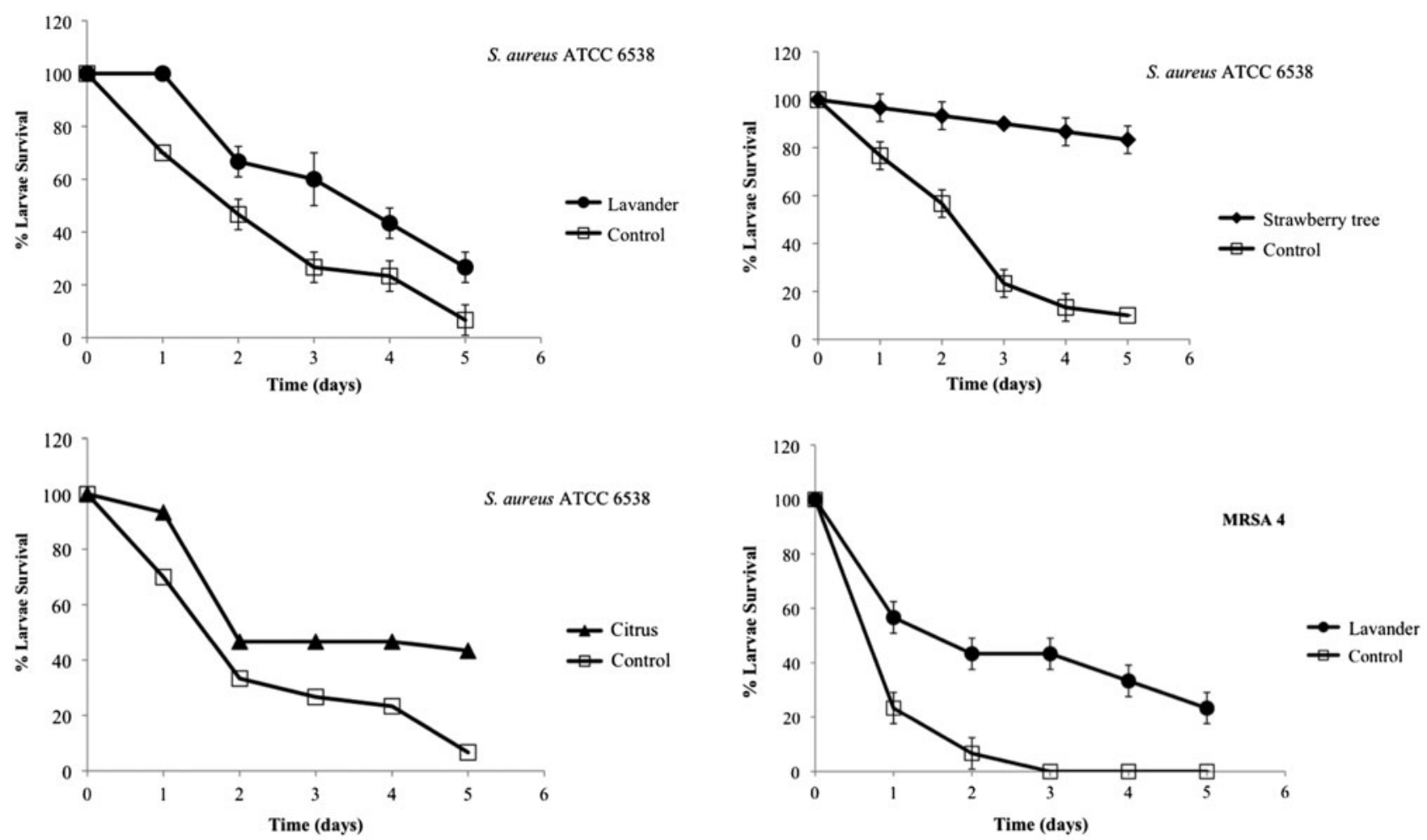

Figure 2. Survival of larvae injected with bacterial cells previously exposed to $25 \% \mathrm{w} / \mathrm{v}$ of lavender, citrus and strawberry tree honey.

Note: Data are the mean of three independent experiments $(n=30)$. The error bars represent the standard deviation.

The larvae injected with PBS maintained a 100\% survival during the five days of the assays. The virulence potential and the antimicrobial action against several human pathogens, including $S$. aureus and $P$. aeruginosa have been estimated by using the $G$. mellonella model (Desbois \& Coote, 2011; Hill, Veli, \& Coote, 2014; Jander, Rahme, \& Ausubel, 2000; Pollitt, West, Crusz, Burton-Chellew, \& Diggle, 20l4). The honey samples tested in our study weakened the virulence potential of $S$. aureus and the MRSA strains but not of the P. aeruginosa strain in this insect model.

$S$. aureus produces several virulence factors that include the haemolysins $\alpha, \beta, \delta, \gamma$, enterotoxins, Toxic Shock Syndrome toxin (TSST), Panton Valentin Leukocidin (PVL) and the exfoliatin $A$ and $B$, which are regulated by the QS system, (Novick, 2003). The virulence and fitness in vivo of $P$. aeruginosa are also coordinated by signaling systems, however they are very diverse and go beyond the acyl homoserine lactones and the PQS. Other systems as the global activator of antibiotic and cyanide synthesis (GAC) system, long chain fatty acids, nucleotide based molecules and pigmented molecules, such as pyoverdine and phenazines have been associated to the virulence signaling network of $P$. aeruginosa (see the review by Jimenez et al., 20I2). In virtue of the complexity of the virulence network of $P$. aeruginosa can be anticipated that the tested honeys failed to affect the virulence potential in a more global manner in comparison to S. aureus. The mode of action of the honeys on the virulence potential strains needs further clarification.

\section{Anti-inflammatory activity}

The inhibitory activity of the hyaluronidase enzyme by the different honeys was determined at 8.93, 17.86, 26.79 and $35.7 \mathrm{I} \mathrm{g} / \mathrm{l}$. The results are illustrated in Figure 3. The lavender honey showed the highest inhibitory activity of the hialuronidase enzyme in comparison to the citrus and strawberry tree honey at any tested concentration $(p<0.05)$ (Figure 3). The strawberry tree honey showed the lowest activity $(p<0.05)$ reaching an inhibition value of $47.93 \pm 1.93 \%$ at the highest concentration tested $(35.7 \mathrm{I} \mathrm{g} / \mathrm{l})$. The citrus honey at this same concentration showed a higher inhibitory value (68.69 $\pm 0.86 \%$ ).

In contrast to the inhibitory activity of the hialuronidase enzyme, the strawberry tree honey showed the highest inhibitory activity $(p<0.05)$ of the lipoxygenase enzyme in comparison to the citrus and lavender honeys reaching $66.07 \pm 0.62 \%$, whereas the lavender and citrus achieved $55.76 \pm 1.20$ and $55.59 \pm 0.24 \%$, respectively. The inhibitory activity of the lipoxygenase enzyme by citrus and lavender honey was similar $(p<0.05)$.

The floral origin of honeys was determinant in the activities found in the present work. Other authors when 

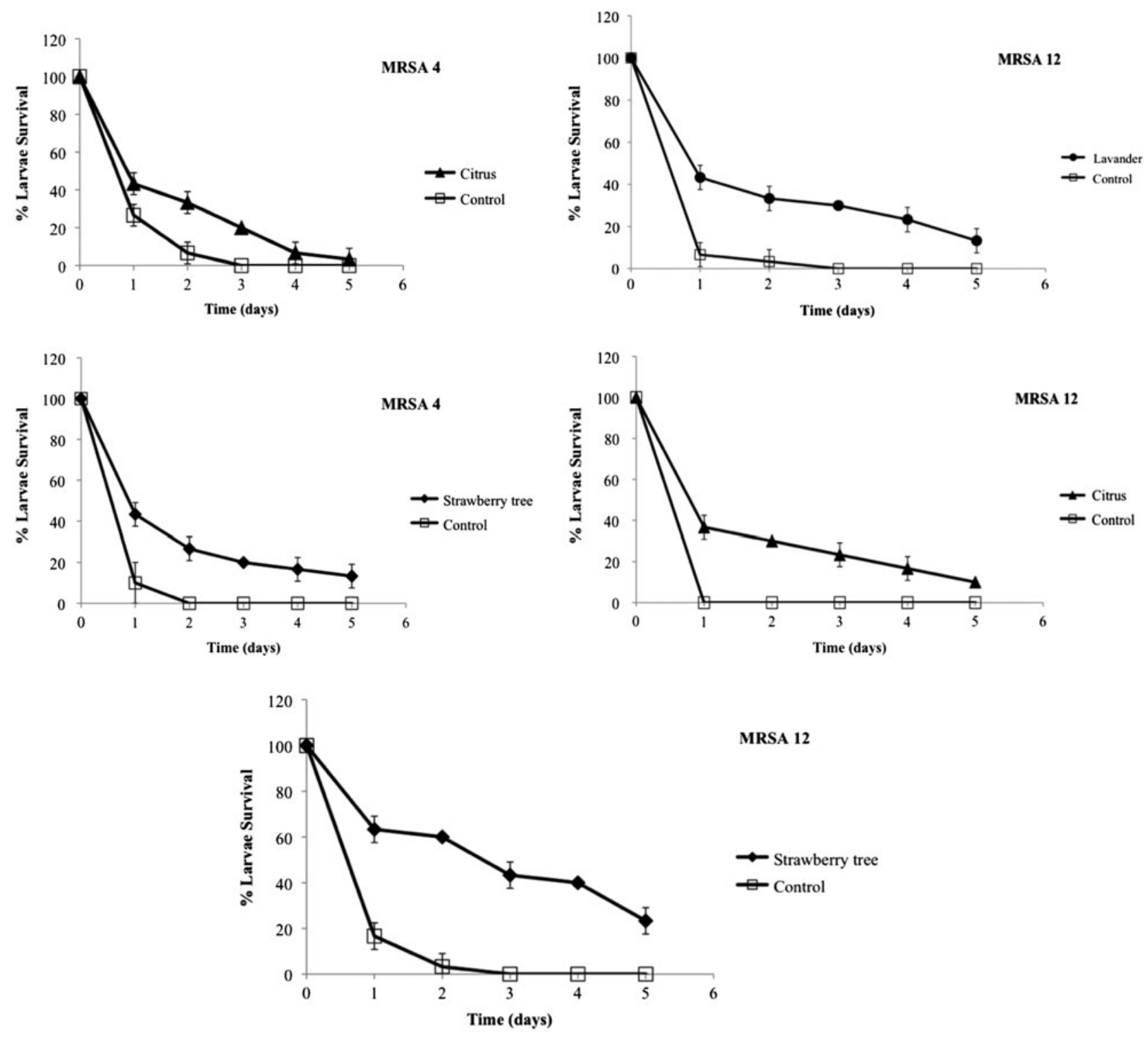

Figure 2. (Continued).

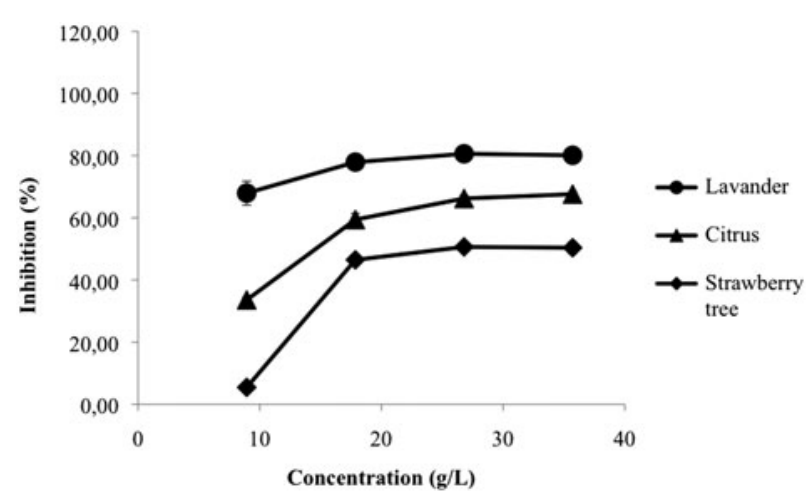

Figure 3. Inhibition of the hyaluronidase enzyme by the different honey samples.

Note: Data are the mean of three assays $(n=9)$. Error bars represent the standard deviation. evaluated, among other activities, the anti-inflammatory properties of different blossom honeys harvested in different countries, also attributed the activities found to the botanical source of honeys (Cimpoiu, Hosu, Miclaus, \& Puscas, 2013; Liu, Ye, Lin, Wang, \& Peng, 20I3). The floral origin of honeys may affect its chemical composition, and therefore the biological properties. Some phenolic compounds have been considered as possible markers of some honeys: homogentisic acid (phenolic acid) and hesperetin (flavanone) for strawberry tree and citrus honeys, respectively, whereas for lavender honey no specific compound could be detected (Bogdanov et al., 2004), although some authors have been reported naringenin (flavanone) as constituent of lavender honey (Andrade, Ferreres, Gil, \& Tomás-Barberán, 1997).

The higher capacity for inhibiting hyaluronidase activity of citrus and lavender honeys than strawberry tree 
honey may be attributed to the presence of flavonoids (de Almeida \& Menezes, 2002).

\section{Conclusions}

The honey samples from Portugal studied in the present study fulfill with the standards for physicochemical parameters, showed excellent microbiological quality and demonstrated antibacterial activity to common and resilient bacterial pathogens, such as MRSA. Adhesion is the first step on the establishment of pathogens either in biotic or abiotic surfaces, and the honey samples were capable to inhibit the adherence of the $S$. aureus, MRSA and $P$. aeruginosa. An important feature of pathogens it is their fitness in vivo, and the honey samples affected the virulence potential of $S$. aureus and the MRSA strains. Furthermore the observed antibacterial activities the honey samples also showed anti-inflammatory activity demonstrating that can combat infection and promote health in different ways.

\section{Acknowledgments}

The authors are thankful to FCT - Fundação para a Ciência e Tecnologia for supporting through the Programme PEst-OE/ EQB/LA0023/2013. The authors are also grateful to Associação dos Apicultores do Sudoeste Alentejano e Costa Vicentina (AASACV) for the honey samples.

\section{Disclosure statement}

The authors report no conflict of interest

\section{ORCID}

Maria Leonor Faleiro (D) http://orcid.org/0000-0002-3878-6948 Maria da Graça Miguel (D) http://orcid.org/0000-0003-2507-4228 Luis Neto (D) http://orcid.org/0000-0003-1834-6459

\section{References}

Aazza, S., Lyoussi, B., Antunes, D., \& Miguel, M. G. (20I3). Physicochemical characterization and antioxidant activity of commercial portuguese honeys. Journal of Food Science, 78, II59-1165.

Abd-El, A. A. M., El-Hadidy, M. R., El-Mashad, N. B., \& ElSebaie, A. H. (2007). Antimicrobial effect of bee honey in comparison to antibiotics isolated from infected burns. Annals of Burns and Fire Disasters, 20, 83-88.

Adrião, A., Vieira, M., Fernandes, I., Barbosa, M., Sol, M., Tenreiro, R. P., ... Faleiro, M. L. (2008). Marked intrastrain variation in response of Listeria monocytogenes dairy isolates to acid or salt stress and the effect of acid or salt adaptation on adherence to abiotic surfaces. International Journal of Food Microbiology, I23, I42-150.

Al, M. L., Daniel, D., Moise, A., Bobis, O., Laslo, L., \& Bogdanov, S. (2009). Physico-chemical and bioactive properties of different floral origin honeys from Romania. Food Chemistry, I/2, 863-867.

Allen, R.C., Popat, R., Diggle, S.P., \& Brown, S.P. (20l4). Targeting virulence: Can we make evolution-Proof drugs? Antibiotic Alternatives - Opinion, 12, 300-308.
Alvarez-Suarez, J. M., Tulipani, S., Díaz, D., Estevez, Y., Romandini, S., Giampieri, F., ... Battino, M. (20/0). Antioxidant and antimicrobial capacity of several monofloral Cuban honeys and their correlation with color, polyphenol content and other chemical compounds. Food and Chemical Toxicology, 48, 2490-2499.

Andrade, P., Ferreres, F., Gil, M. I., \& Tomás-Barberán, F. A. (1997). Determination of phenolic compounds in honeys with different floral origin by capillary zone electrophoresis. Food Chemistry, 60, 79-84.

Badet, C., \& Quero, F. (20II). The in vitro effect of manuka honeys on growth and adherence of oral bacteria. Anaerobe, 17, 19-22.

Belitz, H. D., \& Grosch, W. (1999). Food chemistry (2nd ed.). New York, NY: Springer.

Beretta, G., Granata, P., Ferrero, M., Orioli, M., \& Facino, R. M. (2005). Standardization of antioxidant properties of honey by a combination of spectrophotometric/fluorimetric assays and chemometrics. Analytica Chimica Acta, 533, |85-19|.

Biglari, B., Moghaddam, A., Santos, K., Blaser, G., Büchler, A., Jansen, G., ... Simon, A. (20I2). Multicentre prospective observational study on professional wound care using honey (Medihoney ${ }^{\mathrm{TM}}$ ). International Wound Journal, 10, 252-259.

Bogdanov, S. (1997). Nature and origin of the antibacterial substances in honey. Lebensmittel-Wissenschaft \& Technologie, 30, 748-753.

Bogdanov, S. (2002). Harmonized methods of the international honey commission. Retrieved from http://www.apicultura cluj.com/ApiculturaCluj/italiano/Documents/lHCmethods_e. pdf

Bogdanov, S., Ruoff, K., \& Oddo, L. P. (2004). Physico-chemical methods for the characterisation of unifloral honeys: $A$ review. Apidologie, 35, S4-SI7.

Bogdanov, S., Jurendic, T., Sieber, R., \& Gallmann, P. (2008). Honey for nutrition and health: A review. Journal of the American College of Nutrition, 27, 677-689.

Borrelli, R. C., Visconti, A., Mennella, C., Anese, M., \& Fogliano, V. (2002). Chemical characterization and antioxidant properties of coffee melanoidins. Journal of Agricultural and Food Chemistry, 50, 6527-6533.

Brudzynski, K., \& Kim, L. (20II). Storage-induced chemical changes in active components of honey de-regulate its antibacterial activity. Food Chemistry, 126, II55-1163.

Bukhari, M. H., Khalil, J., Qamar, S., Qamar, Z., Zahid, M., Ansari, N., \& Bakhshi, I. M. (20II). Comparative gastroprotective effects of natural honey, Nigella sativa and cimetidine against acetylsalicylic acid induced gastric ulcer in albino rats. Journal of the College of Physicians Surgeons Pakistan, 2I, I5I-I56.

Campeau, M. E. M., \& Patel, R. (20/4). Antibiofilm activity of manuka honey in combination with antibiotics. International Journal of Bacteriology, 2014, Article ID 79528I, 7 PP. doi: $|0.1| 55 / 20|4 / 79528|$

Camplin, A. L., \& Maddocks, S. E. (20/4). Manuka honey treatment of biofilms of Pseudomonas aeruginosa results in the emergence of isolates with increased honey resistance. Annals of Clinical Microbiology and Antimicrobials, 13, 19. Retrieved from: http://www.ann-clinmicrob.com/content/ $13 / 1 / 19$

Chauzat, M.-P., Cauquil, L., Roy, L., Franco, S., Hendrikx, P., \& Ribière-Chabert, M. (2013). Demographics of the European apicultural industry. PLoS One, 8, e79018.

Cimpoiu, C., Hosu, A., Miclaus, V., \& Puscas, A. (2013). Determination of the floral origin of some Romanian honeys on the basis of physical and biochemical properties. Spectrochimica Acta Part A: Molecular and Biomolecular Spectroscopy, 100, 149-154. 
Codex Alimentarius. (200I). Revised Codex Standard for Honey, Codex STAN 12-198I, Rev. I 1987, Rev. 2.

Cohen, H. A., Rozen, J., Kristal, H., Laks, Y., Berkovitch, M., Uziel, Y., ... Efrat, H. (20I2). Effect of honey on nocturnal cough and sleep quality: A double-blind, randomized, placebo-controlled study. Pediatrics, 130, I-7.

Cooper, R., Jenkins, L., \& Hooper, S. (20I4). Inhibition of biofilms of Pseudomonas aeruginosa by Medihoney in vitro. Journal of Wound Care, 23, 93-104.

Davies, D. G., Parsek, M. R., Pearson, J. P., Iglewski, B. H., Costerton, J. W., \& Greenberg, E. P. (1998). The involvement of cell-to-cell signals in the development of a bacterial biofilm. Science, 280, 295-298.

de Almeida, E. C., \& Menezes, H. (2002). Anti-inflammatory activity of propolis extracts: A review. Journal of Venomous Animals and Toxins including Tropical Diseases, 8, 191-212.

Desbois, A. P., \& Coote, P. J. (20II). Wax moth larva (Galleria mellonella): An in vivo model for assessing the efficacy of antistaphylococcal agents. Journal of Antimicrobial Chemotherapy, 66, 1785-1790.

DR. (2003). Decreto-Lei No. 2/4/2003 (Portuguese Legislation) 18 September 2003.

Erguder, B. I., Kilicoglu, S. S., Namuslu, M., Kilicoglu, B., Devrim, E., Kismet, K., \& Durak, I. (2008). Honey prevents hepatic damage induced by obstruction of the common bile duct. World Journal of Gastroenterology, 14, 3729-3732.

Estevinho, L. M., Feás, X., Seijas, J. A., \& Vázquez-Tato, P. (20I2). Organic honey from Trás-Os-Montes region (Portugal): Chemical, palynological, microbiological and bioactive compounds characterization. Food and Chemical Toxicology, 50, 258-264.

Estevinho, L. M., Pereira, A. P., Moreira, L., Dias, L. G., \& Pereira, E. (2008). Antioxidant and antimicrobial effects of phenolic compounds extracts of Northeast Portugal honey. Food and Chemical Toxicology, 46, 3774-3779.

EU Council. (2002). Council directive 200I/II O/EC of 20 December 2001 relating to honey. Official Journal of the European Communities, LIO, 47-52.

Faleiro, M. L. (20/2). Response of foodborne bacteria to acid shock. In H.-C. Wong (Ed.), Stress response of foodborne pathogens (pp. 35-70). New York, NY: Nova Press.

Fernebro, J. (20II). Fighting bacterial infections-Future treatment options. Drug Resistance Updates, 14, 125-139.

Finola, M. S., Lasagno, M. C., \& Marioli, J. M. (2007). Microbiological and chemical characterization of honeys from central Argentina. Food Chemistry, 100, 1649-1653.

Gomes, S., Dias, L., Moreira, L. L., Rodrigues, P., \& Estevinho, L. (2010). Physicochemical, microbiological and antimicrobial properties of commercial honeys from Portugal. Food and Chemical Toxicology, 48, 544-548.

Granica, S., Czerwińska, M. E., Piwowarski, J. P., Ziaja, M., \& Kiss, A. K. (20/3). Chemical composition, antioxidative and anti-inflammatory activity of extracts prepared from aerial parts of Oenothera biennis L. and Oenothera paradoxa Hudziok obtained after seeds cultivation. Journal of Agricultural and Food Chemistry, 6I, 80I-8I0.

Halstead, F. D., Webber, M. A., Rauf, M., Burt, R., Dryden, M., \& Oppenheim, B. A. (2016). In vitro activity of an engineered honey, medical-grade honeys, and antimicrobial wound dressings against biofilm-producing clinical bacterial isolates. Journal of Wound Care, 25, I-9.

Hill, L., Veli, N., \& Coote, P. J. (20/4). Evaluation of Galleria mellonella larvae for measuring the efficacy and pharmacokinetics of antibiotic therapies against Pseudomonas aeruginosa infection. International Journal of Antimicrobial Agents, 43, 254-26I.
Høiby, N., Bjarnsholt, T., Givskov, M., Molin, S., \& Ciofu, O. (2010a). Antibiotic resistance of bacterial biofilms. International Journal of Antimicrobial Agents, 25, 322-332.

Høiby, N., Ciofu, O., \& Bjarnsholt, T. (2010b). Pseudomonas aeruginosa biofilms in cystic fibrosis. Future Microbiology, 5, $1663-1674$.

Isla, M. I., Craig, A., Ordoñez, R., Zampini, C., Sayago, J., Bedascarrasbure, E., ... Maldonado, L. (20II). Physico chemical and bioactive properties of honeys from Northwestern Argentina. LWT - Food Science and Technology, 44, 1922-1930.

Islam, A., Khalil, I., Islam, N., Moniruzzaman, M., Mottalib, A., Sulaiman, S. A., \& Gan, S. H. (20I2). Physicochemical and antioxidant properties of Bangladeshi honeys stored for more than one year. BMC Complementary and Alternative Medicine, 12, 177.

Jander, G., Rahme, L. G., \& Ausubel, F. M. (2000). Positive Correlation between Virulence of Pseudomonas aeruginosa Mutants in Mice and Insects. Journal of Bacteriology, I82, 3843-3845.

Jenkins, R., Burton, N., \& Cooper, R. (20l4). Proteomic and genomic analysis of methicilin-resistant Staphylococcus aureus (MRSA) exposed to manuka honey in vitro demonstrated down-regulation of virulence markers. Journal of Antimicrobial Chemotherapy, 69, 603-615.

Jenkins, R., Burton, N., \& Cooper, R. A. (20II). Manuka honey inhibits cell division in methicillin-resistant Staphylococcus aureus. Journal of Antimicrobial Chemotherapy, 66, 2536-2542.

Jenkins, R., Wootton, W., Howe, R., \& Cooper, R. (20I2). Susceptibility to manuka honey of Staphylococcus aureus with varying sensitivities to vancomycin. International. Journal of Antimicrobial Agents, 40, 84-93.

Jimenez, P. N., Koch, G., Thompson, J. A., Xavier, K. B., Cool, R. H., \& Quax, W. J. (20I2). The multiple signaling systems regulating virulence in Pseudomonas aeruginosa. Microbiology and Molecular Biology Reviews, 76, 46-65.

Kačániová, M., Pavličová, S., Haščík, P., Kociubinski, G., Kńazovická, V., Sudzina, M., ... Fikselov, M. (2009). Microbial communities in bees, pollen and honey from Slovakia. Acta Microbiologica et Immunologica Hungarica, 56, 285-295.

Lee, J.-H., Park, J.-H., Kim, J.-A., Neupane, G. P., Cho, M. H., Lee, C.-S., \& Lee, J. (20II). Low concentrations of honey reduce biofilm formation, quorum sensing, and virulence, in Escherichia coli OI57:H7. Biofouling, 27, 1095-I 104.

Lin, S. M., Molan, P. C., \& Cursons, R. T. (20II). The controlled in vitro susceptibility of gastrointestinal pathogens to the antibacterial effect of manuka honey. European Journal of Clinical Microbiology \& Infectious Diseases, 30, 569-574.

Liu, J.-R., Ye, Y.-L., Lin, T.-Y., Wang, Y.-W., \& Peng, C.-C. (20I3). Effect of floral sources on the antioxidant, antimicrobial, and anti-inflammatory activities of honeys in Taiwan. Food Chemistry, 139, 938-943.

Lu, J., Turnbull, L., Burke, C. M., Liu, M., Carter, D. A., Schlothauer, R. C., Withchurch, C. B., \& Harry, E. J. (20I4). Manuka-type honeys can eradicate biofilms produced by Staphylococcus aureus strains with different biofilm-forming abilities. Peer], 2326, doi:10.77/7/peerj.326

Maddocks, S. E., Jenkins, R. E., Rowlands, R. S., Purdy, K. J., \& Cooper, R. A. (20I3). Manuka honey inhibits adhesion and invasion of medically important wound bacteria in vitro. Future Microbiology, 8, 1523-1536.

Maddocks, S. E., Lopez, M. S., Rowlands, R. S., \& Cooper, R. A. (20I2). Manuka honey inhibits the development of Streptococcus pyogenes biofilms and causes reduced expression of two fibronectin binding proteins. Microbiology, 158, 78I-790. 
Mendes, E., Brojo Proença, E. B., Ferreira, I. M. P. L. V. O., \& Ferreira, M. A. (1998). Quality of evaluation of Portuguese honey. Carbohydrate Polymers, 37, 219-223.

Miguel, M. G., Antunes, M. D., Aazza, S., Duarte, J., \& Faleiro, M. L. (2013a). Honey-based "água-mel" chemical characterization and microbiological quality. Italian Journal of Food Science, 25, 275-282.

Miguel, M. G., Faleiro, L., Antunes, M. D., Aazza, S., Duarte, J., \& Silvério, A. R. (20/3b). Antimicrobial, antiviral and antioxidant activities of "água-mel" from Portugal. Food and Chemical Toxicology, 56, I36-144.

Naab, O. A., Tamame, M. A., \& Caccavari, M. A. (2008). Palynological and physicochemical characteristics of three unifloral honey types from central Argentina. Spanish Journal of Agricultural Research, 6, 566-576.

Nakamura, Y., Kozuka, M., Naniwa, K., Takabayashi, S., Torikai, K., Hayashi, R., ... Osawa, T. (2003). Arachidonic acid cascade inhibitors modulate phorbols ester-induced oxidative stress in female ICR mouse skin: Differential roles of 5lipoxygenase and cyclooxygenase-2 in leukocyte infiltration and activation. Free Radical Biology \& Medicine, 35, 997-1007.

Nassar, H. M., Li, M., \& Gregory, R. L. (20I2). Effect of honey on Streptococcus mutans growth and biofilm formation. Applied and Environmental Microbiology, 78, 536-540.

Novick, R. P. (2003). Autoinduction and signal transduction in the regulation of staphylococcal virulence. Molecular Microbiology, 48, 1429-1449.

Okhiria, O. A., Henriques, A. F. M., Burton, N. F., Peters, A., \& Cooper, R. A. (2009). Honey modulates biofilms on Pseudomonas aeruginosa in a time and dose dependent manner. Journal of ApiProduct and ApiMedical Science, I, 6-10. doi: I0.3896/IBRA.4.01.1.03

Otto, M. (20I3). Staphylococcal infections: Mechanisms of biofilm maturation and detachment as critical determinants of pathogenicity. Annual Review of Medicine, 64, I75-188.

Paraje, M. G. (20II). Antimicrobial resistance in biofilms. In A Mendez-Vilas (Ed.), Science against microbial pathogens: Communicating current research and technological advances, Microbiology book series-20II (Vol. 2, Pp. 736-744). Badajoz: Formatex Research Center.

Paterson, H. M., Murphy, T. J., Purcell, E. J., Shelley, O., Kriynovich, S. J., Lien, E., ... Lederer, J. A. (2003). Injury primes the innate immune system for enhanced toll-like receptor reactivity. The Journal of Immunology, I 7I, |473-|483.

Patton, T., Barrett, J., Brennan, J., \& Moran, N. (2006). Use of a spectrophotometric bioassay for determination of microbial sensitivity to manuka honey. Journal of Microbiological Methods, 64, 84-95.

Pollitt, E. J., West, S. A., Crusz, S. A., Burton-Chellew, M. N., \& Diggle, S. P. (20I4). Cooperation, quorum sensing, and evolution of virulence in Staphylococcus aureus. Infection and Immunity, 82, 1045-1051.
Roberts, A. E. L., Maddocks, S. E., \& Cooper, R. A. (20I2). Manuka honey is bactericidal against Pseudomonas aeruginosa and results in differential expression of oprF and algD. Microbiology, 158, 3005-3013.

Rodríguez, B. A., Mendoza, S., Iturriga, M. H., \& CastañoTostado, E. (20I2). Quality parameters and antioxidant and antibacterial properties of some Mexican honeys. Journal of Food Science, 7I, CI2I-CI27.

Rosa, A., Tuberoso, C. I. G., Atzeri, A., Melis, M. P., Bifulco, E., \& Dessì, M. A. (20I I). Antioxidant profile of strawberry tree honey and its marker homogentisic acid in several models of oxidative stress. Food Chemistry, 129, 10451053

Sahasrabudhe, A., \& Deodhar, M. (2010). Anti-hyaluronidase, anti-elastase activity of Garcinia indica. International Journal of Botany, 6, 299-303.

Schrama, D., Helliwell, N., Neto, L., \& Faleiro, M. L. (2013). Adaptation of Listeria monocytogenes in a simulated cheese medium: Effects on virulence using the Galleria mellonella infection model. Letters in Applied Microbiology, 5I, $421-427$.

Schuster, M., Lostroh, C. P., Ogi, T., \& Greenberg, E. P. (2003). Identification, timing, and signal specificity of Pseudomonas aeruginosa quorum-controlled genes: A transcriptome analysis. Journal of Bacteriology, I 85, 2066-2079.

Sherlock, O., Dolan, A., Athman, R., Power, A., Gethin, G., Cowman, S., \& Humphreys, H. (20I0). Comparison of the antimicrobial activity of Ulmo honey from Chile and Manuka honey against methicillin-resistant Staphylococcus aureus, Escherichia coli and Pseudomonas aeruginosa. BMC Complementary and Alternative Medicine, 10, 5.

Singleton, V. L., \& Rossi, J. A., Jr. (1965). Colorimetry of total phenolics with phosphomolybdic-phosphotungstic acid reagents. American Journal of Enology and Viticulture, 16, $144-158$.

Tan, H. T., Rahman, R. A., Gan, S. H., Halim, A. S., Hassan, S. A., Sulaiman, S. A., \& Kirnpal-Kaur, B. (2009). The antibacterial properties of Malaysian tualang honey against wound and enteric microorganisms in comparison to manuka honey. BMC Complementary and Alternative Medicine, 9, 57.

Terrab, A., Diez, M. J., \& Heredia, F. J. (2003b). Palynological, physico-chemical and colour characterization of Moroccan honeys: I. River red gum (Eucalyptus camaldulensis Dehnh) honey. International Journal of Food and Science Technology, 38, 379-386.

Terrab, A., González, A. G., Díez, M. J., \& Heredia, F. J. (2003a). Mineral content and electrical conductivity of the honeys produced in Northwest Morocco and their contribution to the characterization of unifloral honeys. Journal of the Science of Food and Agriculture, 83, 637-643.

$\mathrm{Wu}, \mathrm{H}$. (1996). Affecting the activity of soybean lipoxygenaseI. Journal of Molecular Graphics, 14, 33I-337. 